\title{
Підвищення рівня охорони праці та удосконалення методики міжнародної організації праці для оцінки професійних ризиків
}

\section{Богдан Цимбал ${ }^{\mathrm{A}}$; Юрій Древаль ${ }^{\mathrm{B}}$; Артем Петрищев ${ }^{\mathrm{c}}$; Дмитро Шаповалов ${ }^{\mathrm{D}}$; Максим Шаповалов ${ }^{\mathrm{E}}$}

Received: April 10, 2020 | Revised: April 26, 2020 | Accepted: April 30, 2020

DOI: $10.33445 /$ sds.2020.10.2.6

\begin{abstract}
Анотація
В даній роботі представлено аналіз існуючих методик оцінки професійних ризиків. Було розроблено матрицю для оцінки величини професійного ризику та удосконалено методику Міжнародної організації праці для оцінки професійного ризику. Було розроблено п'ять рівнів серйозності наслідків, п'ять рівнів вірогідності шкоди для працівника та величину ризику від мінімального значення 1 (знехтуваний ризик) до максимального - 10 (критичний ризик). Для визначення величини ризиків, які заподіяні фізичними, хімічними, біологічними факторами небезпеки, частотою виникнення нещасного випадку, не-доліками в ергономіці та психологічними перенавантаженнями було розроблено критерії для матриць. Наслідки заподіяної шкоди можуть бути: незначні, легкі, середні, тяжкі та катастрофічні. Удосконалена методика дає можливість врахувати катастрофічні наслідки, які можуть настати під час надзвичайної ситуації, такої як пожежа, вибух, аварія, катастрофа та ін. Вірогідність професійних ризиків може бути: XS - від «eXtra Small» - дуже мала, S - від «Small» - мала, M - від «Medium» - середня, L - від «Large» - велика, XL - від «eXtra Large» - дуже велика та XXL - від «еXtra eXtra Large» - дуже-дуже велика. Удосконалена методика визначає: знехтуваний, малозначний, малий, помірний, прийнятний, допустимий, значимий, недопустимий, максимальний та критичний ризик. Удосконалену методику оцінки професійних ризиків було випробувано на молочному комбінаті. Було встановлено адекватність і точність результатів визначення величини професійного ризику удосконаленої методики порівняно 3 результатами існуючої. Для підвищення рівня охорони праці були запропоновані та впровадженні заходи з управління професійними ризиками.
\end{abstract}

Ключові слова: Міжнародна організація праці, методика оцінки професійних ризиків, експертний метод, знехтуваний ризик, прийнятий ризик, катастрофічний ризик, допустимий ризик, молочний комбінат, заходи з охорони праці, фактори небезпеки.

\section{Постановка проблеми}

Підвищення рівня охорони праці, рівня захисту працівників від професійних ризиків $\epsilon$ першочерговим обов'язком роботодавця та пріоритетним напрямком діяльності усіх керівників та спеціалістів підприємства, установи чи організації. Роботодавець разом

\footnotetext{
АНаціональний університет цивільного захисту України, м. Харків, Україна, к.т.н., ст. викладач кафедри, e-mail: tsembalbogdan@ukr.net, ORCID: 00000002-2317-3428

ВНаціональний університет цивільного захисту України, м. Харків, Україна, д.н.держ.упр, професор, професор кафедри, е-таі: tsembalbogdan@ukr.net, ORCID: 0000-0002-7347-9433

СНаціональний університет «Запорізька політехніка», м. Запоріжжя, Україна, к.т.н., доцент, доцент кафедри, e-mail: kafedrales@ukr.net, ORCID: 00000001-5107-4155

D Національний університет цивільного захисту України, м. Харків, Україна, магістр, e-mail: tsembalbogdan@ukr.net, ORCID: 0000-0003-3208-0925

Е Національний університет цивільного захисту України, м. Харків, Україна, здобувач вищої освіти, e-mail: tsembalbogdan@ukr.net, ORCID: 0000-00025649-528X
} 
зі службою з охорони праці та керівниками повинен надати необхідні засоби та ресурси для оцінки ризиків на робочому місці, поставити завдання, а також визначити осіб, які будуть задіяні у цій роботі. При цьому оцінка професійних ризиків на робочому місці $\epsilon$ комплексним завданням, тому його треба вирішувати групою фахівців, в яку повинні бути включені представники робітників, які безпосередню стикаються 3 небезпеками на робочому місці. Під час проведення оцінки професійного ризику можливо надавати змогу робітникам самостійно ідентифікувати небезпеки, які виникають під час їх трудової діяльності.

\section{Аналіз останніх досліджень та публікацій}

Теоретичні та практичні рішення оцінки ризиків на робочому місці представлені в роботах провідних зарубіжних [1-6] та українських вчених [7-11]. Загалом роботи вчених присвячені як загальним питанням 3 безпеки праці, управлінням охороною праці так і питанням соціального захисту працівників. Однак по теперішній час залишається невирішена проблема створення загальногалузевого, відносно спрощеної методики і відповідно методу, який можливо було $б$ практично використовувати для комплексної оцінки ризиків на робочому місці в системі управління охороною праці будь-яким підприємством, установою чи організацією, незалежно від форм власності.

Сучасні підприємства використовують близько ста якісних, кількісних та комбінованих методів оцінки ризиків на робочому місці [8]. Жоден з цих методів не є універсальним та не дає можливість всебічно та об'єктивно оцінити ризики та урахувати вплив «людського» та зовнішніх чинників. Усі методи $є$ складними, вони потребують від експерта загальногалузевого рівня знань та великої кількості часу, що призводить до того, що процес оцінювання ризиків на робочому місці стає неможливим та формальним [9].

3 метою практичного управління ризиками в інтересах окремого підприємства найбільш підходящими $є$ експертні методи кількісного оцінювання ризиків [3]. При цьому до методик оцінювання виробничих ризиків підприємства повинні ставитися такі вимоги:

1. Методика повинна надавати дані оцінки ризиків в кількісному вигляді.

2. Методика повинна бути простою i наочною, тобто забезпечувати можливість ії застосування тією особою (експертом), для якого вона призначена, з урахуванням рівня його реальної підготовки. В даному випадку це представники молодшого управлінської ланки підприємств (майстер, виконроб, начальник ділянки, бригадир).

3. Методика повинна задовольняти вимогам об'єктивності та відтворюваності отриманих оцінок із заданою точністю (тобто, будь-який експерт, користуючись методикою, повинен отримати одні і ті ж результати за підсумками оцінки ризиків).

Кількісні методики оцінки ризиків додатково дозволяють:

оцінити зміну рівня безпеки на окремому підприємстві протягом певного періоду;

порівняти рівні ризиків підприємств, окремих підрозділів, робочих місць, технологій, відрізняються за галузевою належністю, що застосовується устаткування, рівнем кваліфікації працівників та ін.;

визначити пріоритетні напрямки управління ризиками, оптимізувати розподіл ресурсів для застосування захисних заходів і оцінити результативність цих заходів після їх застосування.

Кількісні методи оцінки ризиків можуть бути прямими і непрямими. Прямі методи оцінки ризиків припускають виявлення потенційних небезпек, експертне оцінювання ймовірності їх прояви в різних варіантах і передбачуваної тяжкості наслідків реалізації кожного варіанту. Непрямі методи оцінки ризиків не припускають безпосереднього виявлення та ідентифікації небезпек на робочих місцях і при виконанні виробничих операцій. Сутність непрямої оцінки ризиків заснована на припущенні урахування всіх (або більшої частини) небезпек в загальних 
нормативних актах 3 охорони праці, промислової та пожежної безпеки (державних, галузевих, локальних).

Крім того, передбачається, що виконання всіх встановлених вищими рівнями управління вимог безпеки забезпечує відсутність ризиків на робочому місці. Безумовно, що останнє твердження помилково, оскільки, відповідно до аксіоматикою безпеки життєдіяльності, ризик, пов'язаний з об'єктом чи діяльністю, не може бути усунутий повністю без ліквідації самого об'єкта або припинення діяльності. Проте, на першому етапі цілеспрямованої діяльності в напрямку поліпшення умов праці це припущення може бути прийнято допустимим.

Одним з непрямих методів кількісної оцінки виробничих ризиків є метод (система) Елмері [4]. Метод Елмері заснований на спостереженнях, які охоплюють всі найважливіші складові частини безпеки праці, такі як: дотримання вимог безпеки при виконанні робіт, стан приміщень і споруд, робочих місць, обладнання, інструментів, застосування працівниками 3І3, порядок на робочому місці, питання гігієни праці та ергономіки.

Недоліком системи Елмері $\epsilon$ те, що всі фактори, що впливають на безпеку праці приймаються рівнозначними (відсутність огороджень під час роботи на висоті, i недостатньої ширини проходи між столами в бухгалтерії). Це в деякій мірі спотворює дійсну картину ризиків організації і не дозволяє планувати заходи 3 охорони праці 3 урахуванням пріоритетності захисних заходів. Незважаючи на це застосування системи Елмері дозволяє планувати заходи з охорони праці не безцільно («для галочки» або з метою витрачання ліміту грошових коштів), а 3 конкретною метою - для усунення виявленої невідповідності. Формування у управлінського персоналу організації сучасних поглядів на планування (а саме - цілеспрямоване планування) діяльності в галузі охорони праці $\epsilon$ одним з найважливіших наріжних каменів сучасної системи управління охороною праці.

Система Елмері є найпростішим методом кількісної оцінки ризиків, який торкається процесів виявлення та ідентифікації небезпек на робочих місцях, оцінки конкретних ризиків. у зв'язку з цим роботодавець не має можливості, наприклад, інформувати працівника про наявних на його робочому місці ризики для здоров'я і життя, а може тільки повідомити працівника: які вимоги охорони праці на його робочому місці виконуються, а які - ні.

Для оцінки професійних ризиків існує метод Кіней та Аува, які є матричними методами. Матриці цих методів можливо використовувати для оцінки ризиків на робочому місці. Ранжирування різних ризиків $\epsilon$ важливим для оцінки прийнятності ризику, залишкового ризику та ранжирування пріоритетів [1]. Метод Аува крім врахування можливої небезпеки та шкідливих наслідків враховує стан робочого середовища, на відміну від Кіней методу, що базуються лише на ймовірності, наслідків та частоти. Метод Аува дещо точніший та надійнішим, оскільки він використовує багато факторів для аналізу ризиків на відміну від Кіней методу [2].

Існує методика, яка дозволяє визначити колективні та індивідуальні професійні ризики, враховуючи залежність експозиції, узагальненого коефіцієнта стану охорони праці та ступеню ризиків. Застосування уніфікованої методики оцінки ризиків дає змогу підвищити рівень профілактичної роботи щодо запобігання нещасним випадкам та професійним захворюванням, посилити контроль за дотриманням вимог законодавчих та нормативно-правових актів з охорони праці на підприємствах гірничорудної галузі [10].

Перевагою цієї методики є: доступність та простота розрахунку; можливість обліку цілого комплексу ризиків; визначення величини ризику через ймовірність будь-якої негативної події. До недоліків методики можна віднести: необхідність визначення точного переліку можливих взаємовпливаючих факторів ризику, який може бути дуже широким. В іншому випадку потрібно буде оцінювати сукупний вплив усіх факторів, що $€$ досить важким; складність визначення ступеня впливу факторів ризику на результати інвестування; складність оцінки ймовірностей настання тієї чи іншої 
події, що визначає дію конкретного фактору ризику.

Реалізація виявленої на робочому місці небезпеки (від обладнання, інструментів, пристосувань, сировини, матеріалів, напівфабрикатів і т.д.) може відбуватися по великій кількості сценаріїв. Тому на практиці дуже часто важко виконати детальний аналіз ризиків та розумніше використовувати якісне ранжування сценаріїв по тяжкості наслідків та ймовірності подій в певному діапазоні. При цьому враховуються: природа шкоди здоров'ю людини від легкого до вкрай важкого, смертельного, а також частини тіла, найімовірніше схильні пошкодження. Ризики класифікують по матриці «ймовірність-збитки» $[5,6]$. Суть методу полягає в тому, що експерт для кожної ситуації визначає ранг ймовірності її настання (наприклад: низька ймовірність, середня ймовірність, висока ймовірність) і відповідний цій ситуації потенційний збиток (наприклад: малий, середній, великий).

На перетині відповідного стовпця і рядка знаходимо шукану умовну величину ризику. При цьому величина ризику може бути представлена і в кількісному вираженні. Цей метод $\epsilon$ найбільш часто вживаним в розвинених країнах через свою простоту. Крім того, оскільки в більшості розвинених країн оцінка ризиків на робочих місцях $\epsilon$ законодавчим обов'язком роботодавця, то застосування такого простого методу дозволяє роботодавцю виконати державну нормативну вимогу 3 охорони праці 3 найменшими витратами.

Безумовним недоліком цього методу $є$ його абсолютна суб'єктивність. Зрозуміло, що різні експерти оцінюватимуть одну і ту ж ситуацію по-різному, ґрунтуючись на особистих знаннях, досвіді, відчуттях, навіть особистому настрої. Не виключено, що один і той же експерт деякий час по тому може оцінити той же ризик на тому ж робочому місці по-іншому. Матричний метод оцінки ризику набув широкого поширення при оцінці ризику під час виконання робіт. Відповідно до цієї методики ризик може приймати три значення: «неприйнятний», «високий» і «прийнятний», що звужує шкалу оцінки. Методика $\epsilon$ матрицею, в якій по вертикалі розташована шкала тяжкості наслідків, а по горизонталі - ймовірність виникнення небезпечної події. Дана методика не дає можливості врахувати катастрофічні явища та їх наслідки, тому удосконалення даної методики є актуальним завданням.

\section{Постановка завдання}

Метою статті $\epsilon$ підвищення рівня охорони праці та удосконалення методики міжнародної організації праці для оцінки професійних ризиків. Для досягнення поставленої мети треба було вирішити наступні завдання:

проаналізувати існуючі методи та медики для оцінки професійного ризику;

розробити п'ятирівневі матриці для удосконалення методики Міжнародної організації праці та визначення величини ризиків, які заподіяні фізичними, хімічними, біологічними факторами небезпеки, частотою виникнення нещасного випадку, недоліками в ергономіці та психологічними перенавантаженнями;

випробувати удосконалену методику на молочному комбінаті;

$$
\text { встановити адекватність і точність }
$$
результатів визначення величини професійного ризику удосконаленої методики порівняно з результатами існуючої;

запропонувати та впровадити заходи 3 управління професійними ризиками.

\section{Виклад основного матеріалу}

Методи та об'єкти дослідження величини професійного ризику

Для оцінки величини професійного ризику було удосконалено методику Міжнародної організації праці [5]. Розроблена матриця для оцінки професійних ризиків (табл. 1), яка має п'ять рівнів серйозності наслідків, п'ять рівнів вірогідності шкоди для працівника та величину ризику від мінімального значення 1 
(знехтуваний ризик) до максимального - 10 (критичний ризик).

Вірогідність професійних ризиків може бути: XS - від «eXtra Small» - дуже мала, S - від
«Small»-мала, M-від «Medium» - середня, Lвід «Large» - велика, XL - від «eXtra Large» дуже велика та XXL - від «eXtra eXtra Large» дуже-дуже велика.

\section{Таблиця 1 - Матриця оцінки величини професійного ризику}

\begin{tabular}{|c|c|c|c|c|c|}
\hline \multirow{2}{*}{ Вірогідність } & \multicolumn{5}{|c|}{ Наслідки } \\
\hline & Незначні & Легкі & Середні & Тяжкі & Катастрофічні \\
\hline $\begin{array}{l}\text { XS - від } \\
\text { «eXtra Small» - } \\
\text { дуже мала }\end{array}$ & $\begin{array}{c}1 \text { Знехтуваний } \\
\text { ризик }\end{array}$ & $\begin{array}{c}2 \text { Малозначний } \\
\text { ризик }\end{array}$ & 3 Малий ризик & 4 Помірний ризик & $\begin{array}{c}5 \text { Прийнятний } \\
\text { ризик }\end{array}$ \\
\hline $\begin{array}{l}\text { S- від «Small» } \\
\text { - мала }\end{array}$ & $\begin{array}{c}2 \text { Малозначний } \\
\text { ризик }\end{array}$ & 3 Малий ризик & $\begin{array}{c}4 \text { Помірний } \\
\text { ризик }\end{array}$ & $\begin{array}{c}5 \text { Прийнятний } \\
\text { ризик }\end{array}$ & $\begin{array}{c}6 \text { Допустимий } \\
\text { ризик }\end{array}$ \\
\hline $\begin{array}{l}\text { М - від «Medium» } \\
\text { - середня }\end{array}$ & 3 Малий ризик & $\begin{array}{c}4 \text { Помірний } \\
\text { ризик }\end{array}$ & $\begin{array}{c}5 \text { Прийнятний } \\
\text { ризик }\end{array}$ & $\begin{array}{c}6 \text { Допустимий } \\
\text { ризик }\end{array}$ & 7 Значимий ризик \\
\hline $\begin{array}{l}\text { L- від «Large» - } \\
\text { великий }\end{array}$ & 4 Помірний ризик & $\begin{array}{c}5 \text { Прийнятний } \\
\text { ризик }\end{array}$ & $\begin{array}{c}6 \text { Допустимий } \\
\text { ризик }\end{array}$ & 7 Значимий ризик & $\begin{array}{c}8 \text { Недопустимий } \\
\text { ризик }\end{array}$ \\
\hline $\begin{array}{lr}\mathrm{XL}- & \text { від } \\
\text { «eXtra Large» } & - \\
\text { дуже велика } & \\
\end{array}$ & $\begin{array}{c}5 \text { Прийнятний } \\
\text { ризик }\end{array}$ & $\begin{array}{c}6 \text { Допустимий } \\
\text { ризик }\end{array}$ & $\begin{array}{c}7 \text { Значимий } \\
\text { ризик }\end{array}$ & $\begin{array}{c}8 \text { Недопустимий } \\
\text { ризик }\end{array}$ & $\begin{array}{c}9 \text { Максимальний } \\
\text { ризик }\end{array}$ \\
\hline $\begin{array}{l}\text { XXL - від «eXtra } \\
\text { eXtra Large» - } \\
\text { дуже-дуже велика }\end{array}$ & $\begin{array}{c}6 \text { Допустимий } \\
\text { ризик }\end{array}$ & $\begin{array}{c}7 \text { Значимий } \\
\text { ризик }\end{array}$ & $\begin{array}{c}8 \text { Недопустимий } \\
\text { ризик }\end{array}$ & $\begin{array}{c}9 \text { Максимальний } \\
\text { ризик }\end{array}$ & $\begin{array}{c}10 \text { Критичний } \\
\text { ризик }\end{array}$ \\
\hline
\end{tabular}

Удосконалена методика визначає: знехтуваний, малозначний, малий, помірний, прийнятний, допустимий, значимий, недопустимий, максимальний та критичний ризик. Наслідки заподіяної шкоди можуть бути: незначні, легкі, середні, тяжкі та катастрофічні. Удосконалена методика дає можливість врахувати катастрофічні наслідки, які можуть настати під час надзвичайної ситуації, такої як пожежа, вибух, аварія, катастрофа та ін.

Для визначення величини ризиків, які заподіяні фізичними (табл. 2), хімічними (табл.
3), біологічними факторами небезпеки (табл. 4), частотою виникнення нещасного випадку (табл. 5), недоліками в ергономіці (табл. 6) та психологічними перенаванта-женнями (табл. 7) було розроблено критерії для матриць.

Удосконалена методика надає можливість більш точно оцінити ризик на робочому місці у великому інтервалі часу, ступенем дії на організм людини враховуючи нормативне значення, врахувати всі наслідки, які можуть трапитися при дії того чи іншого фактору небезпеки.

Таблиця 2 - Матриця оцінки величини професійного ризику, які спричинені фізичними факторами

\begin{tabular}{|c|c|c|c|c|c|}
\hline \multirow[b]{2}{*}{ Вірогідність } & \multicolumn{5}{|c|}{ Наслідки } \\
\hline & $\begin{array}{c}\text { Незначні } \\
\text { Дискомфорт, } \\
\text { перевтома }\end{array}$ & $\begin{array}{c}\text { Легкі } \\
\text { Незручний стан, } \\
\text { роздратування, } \\
\text { мінлива слабка } \\
\text { хвороба }\end{array}$ & $\begin{array}{c}\text { Середні } \\
\text { Опіки, тривалі } \\
\text { серйозні впливи, } \\
\text { тривала легка } \\
\text { шкода, } \\
\text { перешкоди } \\
\text { органам слуху. }\end{array}$ & $\begin{array}{c}\text { Тяжкі } \\
\text { Рак, який } \\
\text { викликано родом } \\
\text { роботи, астма, } \\
\text { тривалі серйозні } \\
\text { впливи, які } \\
\text { можуть призвести } \\
\text { до смерті }\end{array}$ & $\begin{array}{c}\text { Катастрофічні } \\
\text { Променева } \\
\text { хвороба, тривалі } \\
\text { серйозні впливи, } \\
\text { тривала важка } \\
\text { шкода, раптова } \\
\text { смерть. }\end{array}$ \\
\hline 1 & 2 & 3 & 4 & 5 & 6 \\
\hline $\begin{array}{l}\text { XS - від «eXtra } \text { Small» } \\
\text { дуже мала } \\
\text { Вплив до } 10 \% \\
\text { нормативних величин }\end{array}$ & $\begin{array}{c}1 \text { Знехтуваний } \\
\text { ризик }\end{array}$ & $\begin{array}{c}2 \text { Малозначний } \\
\text { ризик }\end{array}$ & 3 Малий ризик & 4 Помірний ризик & 5 Прийнятний ризик \\
\hline \begin{tabular}{|l} 
S- від «Small»-мала \\
Вплив від 10-25\% від \\
нормативних величин
\end{tabular} & $\begin{array}{c}2 \text { Малозначний } \\
\text { ризик }\end{array}$ & 3 Малий ризик & 4 Помірний ризик & 5 Прийнятний ризик & 6 Допустимий ризик \\
\hline
\end{tabular}




\begin{tabular}{|c|c|c|c|c|c|}
\hline 1 & 2 & 3 & 4 & 5 & 6 \\
\hline 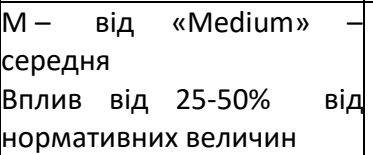 & 3 Малий ризик & 4 Помірний ризик & 5 Прийнятний ризик & 6 Допустимий ризик & 7 Значимий ризик \\
\hline $\begin{array}{l}\text { L- від «Large»-великий } \\
\text { Вплив від 50-100\% від } \\
\text { нормативних величин }\end{array}$ & $\begin{array}{c}4 \text { Помірний } \\
\text { ризик }\end{array}$ & $\begin{array}{c}5 \text { Прийнятний } \\
\text { ризик }\end{array}$ & 6 Допустимий ризик & 7 Значимий ризик & $\begin{array}{c}8 \text { Недопустимий } \\
\text { ризик }\end{array}$ \\
\hline $\begin{array}{l}\text { XL - від «eXtra Large» } \\
\text { дуже велика } \\
\text { Вплив від 100-150\% від } \\
\text { нормативних величин }\end{array}$ & $\begin{array}{c}5 \text { Прийнятний } \\
\text { ризик }\end{array}$ & $\begin{array}{c}6 \text { Допустимий } \\
\text { ризик }\end{array}$ & 7 Значимий ризик & $\begin{array}{c}8 \text { Недопустимий } \\
\text { ризик }\end{array}$ & $\begin{array}{c}9 \text { Максимальний } \\
\text { ризик }\end{array}$ \\
\hline \begin{tabular}{|ll} 
XXL-від «eXtra eXtra \\
Large»-дуже-дуже велика \\
Вплив понад $150 \%$ \\
нормативних величин
\end{tabular} & $\begin{array}{c}6 \text { Допустимий } \\
\text { ризик }\end{array}$ & 7 Значимий ризик & $\begin{array}{c}8 \text { Недопустимий } \\
\text { ризик }\end{array}$ & $\begin{array}{c}9 \text { Максимальний } \\
\text { ризик }\end{array}$ & 10 Критичний ризик \\
\hline
\end{tabular}

Таблиця 3 - Матриця оцінки величини професійного ризику, які спричинені хімічними факторами

\begin{tabular}{|c|c|c|c|c|c|}
\hline \multirow[b]{2}{*}{ Вірогідність } & \multicolumn{5}{|c|}{ Наслідки } \\
\hline & $\begin{array}{c}\text { Незначні } \\
\text { Дискомфорт } \\
\text { та/або } \\
\text { малозначний } \\
\text { вплив на } \\
\text { організм } \\
\text { R-фрази ризику: } \\
\text { R66, } 67\end{array}$ & \begin{tabular}{|c|} 
Легкі \\
Легко мінливе \\
легке \\
захворювання, \\
роздратування \\
R-фрази ризику: \\
R20, 21, 22, 36, \\
37,38
\end{tabular} & \begin{tabular}{|c} 
Середні \\
Не постійна \\
короткотривала \\
легка шкода, \\
признаки \\
проблеми з \\
диханням, хімічні \\
опіки 1-2 ступеня \\
R-фрази ризику: \\
R23, 24, 25, 31, 34
\end{tabular} & $\begin{array}{c}\text { Тяжкі } \\
\text { Постійні серйозні } \\
\text { довготривалі } \\
\text { впливи, постійна } \\
\text { легка шкода, } \\
\text { хімічні опіки 3-4 } \\
\text { ступеню, астма, } \\
\text { алергічні реакції } \\
\text { R-фрази ризику: } \\
\text { R27, 28, 29, 32, 33, } \\
35,40,41,48,65\end{array}$ & \begin{tabular}{|c|} 
Катастрофічні \\
Професійний рак, \\
постійні серйозні \\
впливи, хронічні \\
захворювання, які \\
скорочують життя, \\
пожежа, вибух, \\
смерть \\
R-фрази ризику: \\
R1, 2, 3, 4, 5, 6, 7, 8, 9, \\
$10,11,12,13,14,15$, \\
$16,17,18,19,30,39$, \\
$42,43,44,45,49,60$, \\
$61,62,63,64,68$ \\
\end{tabular} \\
\hline 1 & 2 & 3 & 4 & 5 & 6 \\
\hline $\begin{array}{l}\text { XS - від «eXtra Small» } \\
\text { дуже мала } \\
\text { Хімічні речовини майже не } \\
\text { застосовуються. Ïх вміст } \\
\text { дуже низький, до } 10 \% \text { від } \\
\text { нормативного значення }\end{array}$ & $\begin{array}{c}1 \text { Знехтуваний } \\
\text { ризик }\end{array}$ & $\begin{array}{c}2 \text { Малозначний } \\
\text { ризик }\end{array}$ & 3 Малий ризик & 4 Помірний ризик & 5 Прийнятний ризик \\
\hline $\mid \begin{array}{ll}\text { S- від «Small» - мала } \\
\text { Хімічні } & \text { речовини } \\
\text { застосовуються щорічно. Ïx } \\
\text { вміст від } \quad 10-25 \% \quad \text { від } \\
\text { нормативного значення } \\
\end{array}$ & $\begin{array}{c}2 \text { Малозначний } \\
\text { ризик }\end{array}$ & 3 Малий ризик & 4 Помірний ризик & $\begin{array}{c}5 \text { Прийнятний } \\
\text { ризик }\end{array}$ & 6 Допустимий ризик \\
\hline $\begin{array}{|lrl|}\text { М- від } & \text { «Medium» } \\
\text { середня } & \\
\text { Хімічні } & \text { речовини } \\
\text { застосовуються щосезонне. } \\
\text { їх вміст помірний від } 25- \\
50 \% \text { від } \\
\text { значення } & \\
\text { нормативного }\end{array}$ & 3 Малий ризик & $\begin{array}{c}4 \text { Помірний } \\
\text { ризик }\end{array}$ & $\begin{array}{c}5 \text { Прийнятний } \\
\text { ризик }\end{array}$ & $\begin{array}{c}6 \text { Допустимий } \\
\text { ризик }\end{array}$ & 7 Значимий ризик \\
\hline $\begin{array}{|ll|}\text { L- від «Large» - великий } \\
\text { Хімічні } & \text { речовини } \\
\text { застосовуються } & \text { щомісячно. } \\
\text { Ïх вміст від } & 50-100 \% \text { від } \\
\text { нормативного значення }\end{array}$ & $\begin{array}{l}4 \text { Помірний } \\
\text { ризик }\end{array}$ & $\begin{array}{c}5 \text { Прийнятний } \\
\text { ризик }\end{array}$ & $\begin{array}{c}6 \text { Допустимий } \\
\text { ризик }\end{array}$ & 7 Значимий ризик & $\begin{array}{c}8 \text { Недопустимий } \\
\text { ризик }\end{array}$ \\
\hline $\begin{array}{|ll|}\mathrm{XL}-\text { від } \text { «еXtra Large» } \\
\text { дуже велика } \\
\text { Хімічні } & \\
\text { застосовуються } & \text { щечовини } \\
\text { щодно. }\end{array}$ & $\begin{array}{c}5 \text { Прийнятний } \\
\text { ризик }\end{array}$ & $\begin{array}{c}6 \text { Допустимий } \\
\text { ризик }\end{array}$ & 7 Значимий ризик & $\begin{array}{c}8 \text { Недопустимий } \\
\text { ризик }\end{array}$ & $\begin{array}{c}9 \text { Максимальний } \\
\text { ризик }\end{array}$ \\
\hline
\end{tabular}




\begin{tabular}{|l|c|c|c|c|c|}
\hline \hline 1 & 2 & 3 & 4 & 5 & \\
\hline $\begin{array}{l}\text { Проявляються ознаки ї } \\
\text { впливу, іх вміст від 100- } \\
150 \% \text { від нормативного } \\
\text { значення }\end{array}$ & & & & \\
\hline $\begin{array}{l}\text { XXL-від «еXtra eXtra Large» } \\
\text { дуже-дуже велика } \\
\text { Хімічні речовини } \\
\text { застосовуються щогодинне. } \\
\text { Дуже характерні ознаки ї } \\
\text { впливу, іх вміст понад 150\%. }\end{array}$ & $\begin{array}{c}\text { Допустимий } \\
\text { ризик }\end{array}$ & $\begin{array}{c}\text { 7 Значимий } \\
\text { ризик }\end{array}$ & $\begin{array}{c}\text { 8 Недопустимий } \\
\text { ризик }\end{array}$ & $\begin{array}{c}\text { М Максимальний } \\
\text { ризик }\end{array}$ & 10 Критичний ризик \\
\hline
\end{tabular}

Відповідно до Директиви Комісії положень, що стосуються класифікації, 2001/59/ЄС від 6 серпня 2001 року про упаковки та маркування небезпечних пристосування технічного прогресу в 28 раз речовин, R вирази використовуються в Директиву Ради 67/548/ЄEC про наближення міжнародних картах безпеки хімічних законів, правил та адміністративних речовин для класифікації ризиків.

Таблиця 4 - Матриця оцінки величини професійного ризику, які спричинені біологічними факторами

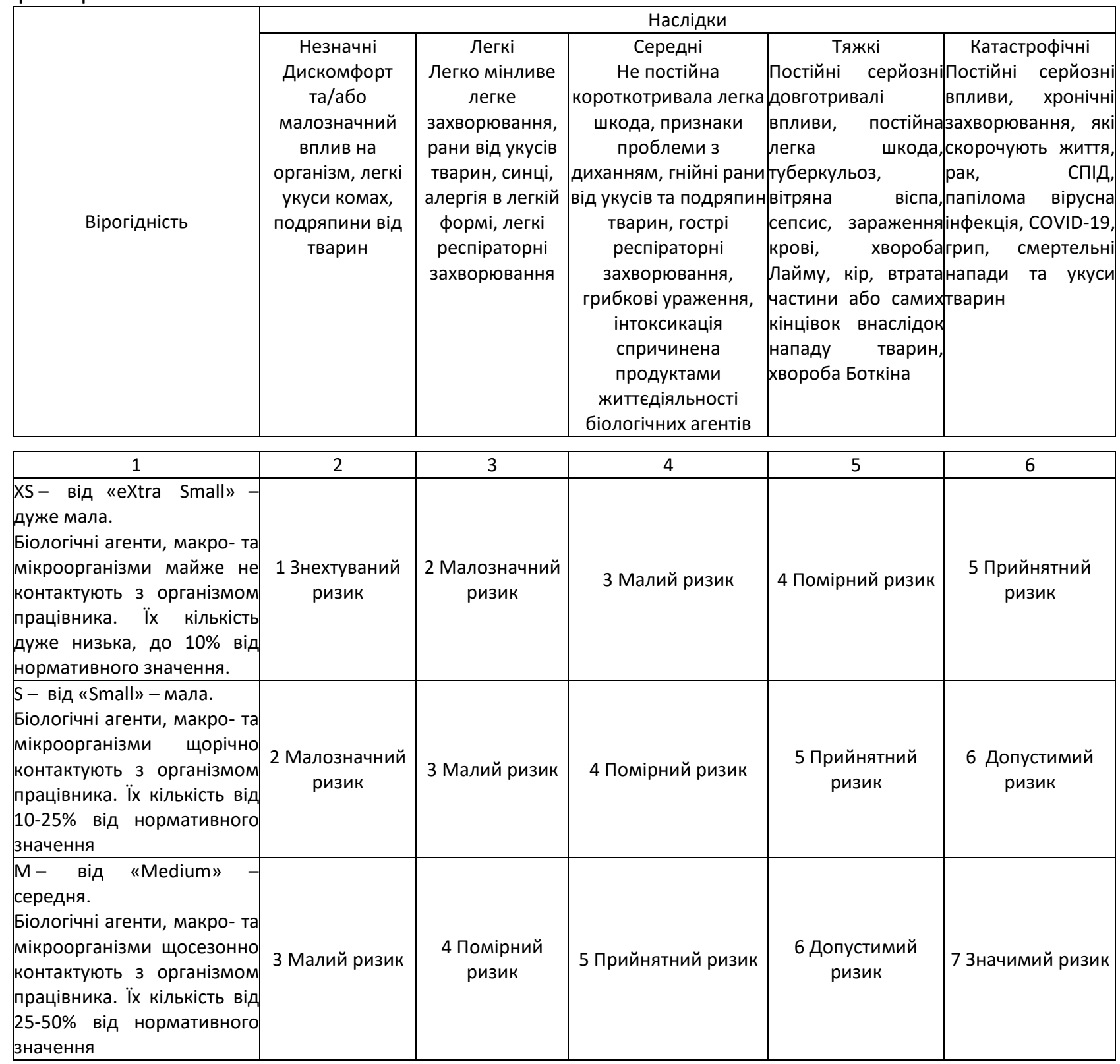




\begin{tabular}{|c|c|c|c|c|c|}
\hline 1 & 2 & 3 & 4 & 5 & 6 \\
\hline $\begin{array}{l}\text { L- від «Large» - великий. } \\
\text { Біологічні агенти, макро- та } \\
\text { мікроорганізми щомісячно } \\
\text { контактують з організмом } \\
\text { працівника. Їх кількість від } \\
50-100 \% \text { від нормативного } \\
\text { значення }\end{array}$ & $\begin{array}{l}4 \text { Помірний } \\
\text { ризик }\end{array}$ & $\begin{array}{c}5 \text { Прийнятний } \\
\text { ризик }\end{array}$ & 6 Допустимий ризик & 7 Значимий ризик & $\begin{array}{c}8 \text { Недопустимий } \\
\text { ризик }\end{array}$ \\
\hline $\begin{array}{l}\mathrm{XL}-\text { від «еXtra Large» } \\
\text { дуже велика. } \\
\text { Біологічні агенти, макро- та } \\
\text { мікроорганізми щоденно } \\
\text { контактують з організмом } \\
\text { працівника. Їх кількість від } \\
100-150 \% \text { від нормативного } \\
\text { значення }\end{array}$ & $\begin{array}{c}5 \text { Прийнятний } \\
\text { ризик }\end{array}$ & $\begin{array}{c}6 \text { Допустимий } \\
\text { ризик }\end{array}$ & 7 Значимий ризик & $\begin{array}{c}8 \text { Недопустимий } \\
\text { ризик }\end{array}$ & $\begin{array}{c}9 \text { Максимальний } \\
\text { ризик }\end{array}$ \\
\hline 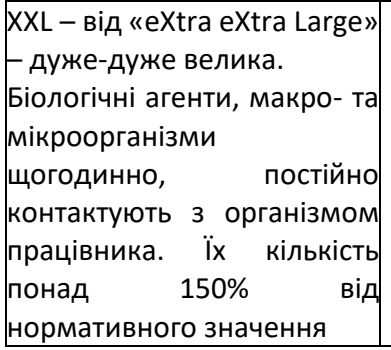 & $\begin{array}{c}6 \text { Допустимий } \\
\text { ризик }\end{array}$ & $\begin{array}{c}7 \text { Значимий } \\
\text { ризик }\end{array}$ & $\begin{array}{c}8 \text { Недопустимий } \\
\text { ризик }\end{array}$ & $\begin{array}{c}9 \text { Максимальний } \\
\text { ризик }\end{array}$ & $\begin{array}{c}10 \text { Критичний } \\
\text { ризик }\end{array}$ \\
\hline
\end{tabular}

Таблиця 5 - Матриця оцінки величини професійного ризику, спричиненого частотою виникнення нещасного випадку

\begin{tabular}{|c|c|c|c|c|c|}
\hline \multirow[b]{2}{*}{ Вірогідність } & \multicolumn{5}{|c|}{ Наслідки } \\
\hline & \begin{tabular}{|c|} 
Незначні \\
Відсутність на \\
робочому місці \\
до 3 годин. \\
Незначні впливи, \\
головний біль, \\
гіпер- або \\
гіпотонія
\end{tabular} & \begin{tabular}{|c|} 
Легкі \\
Відсутність на \\
роботі від 3 \\
годин до 3 \\
робочих днів. \\
Легкі впливи, \\
пошкодження \\
кожного \\
покрову та/або \\
поява гематоми \\
на тілі, легкі \\
простудні \\
захворювання \\
\end{tabular} & \begin{tabular}{|c|} 
Середні \\
Відсутності від 3 до \\
10 днів. \\
Не довгі серйозні \\
наслідки, постійні \\
слабкі ушкодження: \\
розтягнення м'язів \\
та/ або вивихи, \\
гострі респіраторні \\
захворювання без \\
ускладнень, легкі \\
опіки 1-2 ступеня
\end{tabular} & \begin{tabular}{|c|} 
Тяжкі \\
Відсутність на роботі \\
від 10 до 90 робочих \\
днів. \\
Довготривалі \\
серйозні наслідки, \\
постійні сильні \\
ушкодження: \\
наслідки після \\
тяжких переломів \\
та/або опіків 3-4 \\
ступеня
\end{tabular} & \begin{tabular}{|c|} 
Катастрофічні \\
Відсутності більше \\
90 днів. \\
Постійна \\
непрацездатність, \\
інвалідність або \\
смерть
\end{tabular} \\
\hline 1 & 2 & 3 & 4 & 5 & 6 \\
\hline \begin{tabular}{|l|} 
XS - від «eXtra Small» \\
дуже мала \\
Випадкові та небезпечні \\
ситуації виникають рідко \\
\end{tabular} & $\begin{array}{c}1 \text { Знехтуваний } \\
\text { ризик }\end{array}$ & $\begin{array}{c}2 \text { Малозначний } \\
\text { ризик }\end{array}$ & 3 Малий ризик & 4 Помірний ризик & 5 Прийнятний ризик \\
\hline 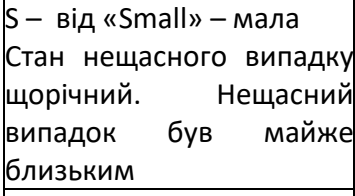 & $\begin{array}{c}2 \text { Малозначний } \\
\text { ризик }\end{array}$ & 3 Малий ризик & 4 Помірний ризик & 5 Прийнятний ризик & 6 Допустимий ризик \\
\hline $\begin{array}{l}\text { М- від «Medium» } \\
\text { середня } \\
\text { Стан нещасного випадку } \\
\text { щосезонний. Нещасний } \\
\text { випадок був близьким }\end{array}$ & 3 Малий ризик & $\begin{array}{l}4 \text { Помірний } \\
\text { ризик }\end{array}$ & 5 Прийнятний ризик & 6 Допустимий ризик & 7 Значимий ризик \\
\hline $\begin{array}{l}\text { L- від «Large»-великий } \\
\text { Стан нещасного випадку } \\
\text { щомісячний. Нещасний } \\
\text { випадок майже відбувся }\end{array}$ & $\begin{array}{l}4 \text { Помірний } \\
\text { ризик }\end{array}$ & $\begin{array}{c}5 \text { Прийнятний } \\
\text { ризик }\end{array}$ & 6 Допустимий ризик & 7 Значимий ризик & $\begin{array}{c}8 \text { Недопустимий } \\
\text { ризик }\end{array}$ \\
\hline $\begin{array}{l}\text { XL - від «eXtra Large» } \\
\text { дуже велика }\end{array}$ & $\begin{array}{c}5 \text { Прийнятний } \\
\text { ризик }\end{array}$ & $\begin{array}{c}6 \text { Допустимий } \\
\text { ризик }\end{array}$ & 7 Значимий ризик & $\begin{array}{c}8 \text { Недопустимий } \\
\text { ризик }\end{array}$ & $\begin{array}{c}9 \text { Максимальний } \\
\text { ризик }\end{array}$ \\
\hline
\end{tabular}




\begin{tabular}{|c|c|c|c|c|c|}
\hline 1 & 2 & 3 & 4 & 5 & 6 \\
\hline $\begin{array}{|lrr|}\text { Стан нещасного випадку } \\
\text { щоденний. } & \text { Нещасний } \\
\text { випадок } & \text { був } & \text { дуже } \\
\text { близьким } & \text { до } & \text { його } \\
\text { настання } & & \\
\end{array}$ & & & & & \\
\hline 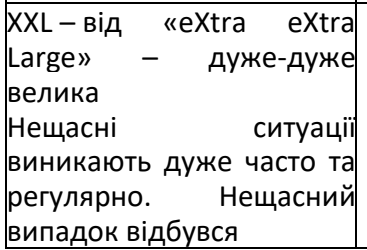 & $\begin{array}{c}6 \text { Допустимий } \\
\text { ризик }\end{array}$ & $\begin{array}{c}7 \text { Значимий } \\
\text { ризик }\end{array}$ & $\begin{array}{c}8 \text { Недопустимий } \\
\text { ризик }\end{array}$ & $\begin{array}{c}9 \text { Максимальний } \\
\text { ризик }\end{array}$ & 10 Критичний ризик \\
\hline
\end{tabular}

Таблиця 6 - Матриця оцінки величини професійного ризику, викликаного недоліками в ергономіці

\begin{tabular}{|c|c|c|c|c|c|}
\hline \multirow[b]{2}{*}{ Вірогідність } & \multicolumn{5}{|c|}{ Наслідки } \\
\hline & \begin{tabular}{|c|} 
Незначні \\
Незначна \\
неприємність та/або \\
легка втома \\
\end{tabular} & \begin{tabular}{|c|} 
Легкі \\
Короткотривалі \\
незначні впливи, \\
не постійна і \\
незначна шкода, \\
випадкова \\
відсутність \\
\end{tabular} & \begin{tabular}{|c|} 
Середні \\
Довготривалі не \\
серйозні, постійні \\
впливи, постійна \\
незначна шкода, \\
повторювальна \\
відсутність \\
\end{tabular} & \begin{tabular}{|c|} 
Тяжкі \\
Короткотривалі \\
серйозні, постійні \\
впливи, постійна \\
значна шкода, довгі \\
відсутності
\end{tabular} & \begin{tabular}{|c|} 
Катастрофічні \\
Довготривалі \\
серйозні, постійні \\
впливи, постійні \\
відсутності
\end{tabular} \\
\hline $\begin{array}{|ll|}\text { XS - від «eXtra } & \text { Small» } \\
\text { дуже мала } & \\
\text { Навантаження } & \\
\text { випадкове, } & \text { виникає } \\
\text { рідко } & \\
\end{array}$ & 1 Знехтуваний ризик & $\begin{array}{c}2 \text { Малозначний } \\
\text { ризик }\end{array}$ & 3 Малий ризик & 4 Помірний ризик & $\begin{array}{c}5 \text { Прийнятний } \\
\text { ризик }\end{array}$ \\
\hline \begin{tabular}{|l|} 
S- від «Small»- - мала \\
Ситуація небезпеки та \\
навантаження щорічно
\end{tabular} & $\begin{array}{c}2 \text { Малозначний } \\
\text { ризик }\end{array}$ & 3 Малий ризик & 4 Помірний ризик & $\begin{array}{c}5 \text { Прийнятний } \\
\text { ризик }\end{array}$ & $\begin{array}{c}6 \text { Допустимий } \\
\text { ризик }\end{array}$ \\
\hline \begin{tabular}{|l|} 
M- від «Medium» \\
середня \\
Ситуація небезпеки та \\
навантаження \\
щосезонне
\end{tabular} & 3 Малий ризик & 4 Помірний ризик & $\begin{array}{c}5 \text { Прийнятний } \\
\text { ризик }\end{array}$ & $\begin{array}{c}6 \text { Допустимий } \\
\text { ризик }\end{array}$ & 7 Значимий ризик \\
\hline $\begin{array}{l}\text { L- від «Large»-великий } \\
\text { Ситуація небезпеки та } \\
\text { навантаження } \\
\text { щомісячно }\end{array}$ & 4 Помірний ризик & $\begin{array}{c}5 \text { Прийнятний } \\
\text { ризик }\end{array}$ & $\begin{array}{c}6 \text { Допустимий } \\
\text { ризик }\end{array}$ & 7 Значимий ризик & $\begin{array}{c}8 \text { Недопустимий } \\
\text { ризик }\end{array}$ \\
\hline \begin{tabular}{|l|}
$\mathrm{XL}-$ від «eXtra Large» \\
дуже велика \\
Ситуація небезпеки та \\
навантаження щоденно \\
\end{tabular} & 5 Прийнятний ризик & $\begin{array}{c}6 \text { Допустимий } \\
\text { ризик }\end{array}$ & 7 Значимий ризик & $\begin{array}{c}8 \text { Недопустимий } \\
\text { ризик }\end{array}$ & $\begin{array}{c}9 \text { Максимальний } \\
\text { ризик }\end{array}$ \\
\hline \begin{tabular}{|l}
$\mathrm{XXL}-$ від $\quad$ "XXtra eXtra \\
Large» $\quad$ дуже-дуже \\
велика \\
Ситуація небезпеки та \\
навантаження \\
щогодинне (постійне) \\
\end{tabular} & 6 Допустимий ризик & 7 Значимий ризик & $\begin{array}{c}8 \text { Недопустимий } \\
\text { ризик }\end{array}$ & $\begin{array}{c}9 \text { Максимальний } \\
\text { ризик }\end{array}$ & $\begin{array}{c}10 \text { Критичний } \\
\text { ризик }\end{array}$ \\
\hline
\end{tabular}

Таблиця 7 - Матриця оцінки величини професійного ризику, спричиненого психологічними перенавантаженнями

\begin{tabular}{|c|c|c|c|c|c|}
\hline \multirow[b]{2}{*}{ Вірогідність } & \multicolumn{5}{|c|}{ Наслідки } \\
\hline & $\begin{array}{c}\text { Незначні } \\
\text { Втома, суєта, } \\
\text { випадкова } \\
\text { відсутність }\end{array}$ & $\begin{array}{c}\text { Легкі } \\
\text { Роздратованість, } \\
\text { низька здатність } \\
\text { концентрації та } \\
\text { роботи, мала } \\
\text { відсутність }\end{array}$ & $\begin{array}{c}\text { Середні } \\
\text { Нервовий зрив, } \\
\text { постійні, сильні } \\
\text { стреси, паніка, } \\
\text { занепокоєння, } \\
\text { повторювальна } \\
\text { відсутність } \\
\end{array}$ & $\begin{array}{c}\text { Тяжкі } \\
\text { Безпорадність, } \\
\text { мінлива, сезонна } \\
\text { депресія, не } \\
\text { постійна, але } \\
\text { велика відсутність }\end{array}$ & \begin{tabular}{|c|} 
Катастрофічні \\
Безнадійність, \\
невроз, сильна \\
депресія, постійна \\
відсутність
\end{tabular} \\
\hline 1 & 2 & 3 & 4 & 5 & 6 \\
\hline $\begin{array}{l}\text { XS - від «eXtra Small» - } \\
\text { дуже мала }\end{array}$ & $\begin{array}{c}1 \text { Знехтуваний } \\
\text { ризик }\end{array}$ & $\begin{array}{c}2 \text { Малозначний } \\
\text { ризик }\end{array}$ & 3 Малий ризик & 4 Помірний ризик & $\begin{array}{c}5 \text { Прийнятний } \\
\text { ризик }\end{array}$ \\
\hline
\end{tabular}




\begin{tabular}{|c|c|c|c|c|c|}
\hline 1 & 2 & 3 & 4 & 5 & 6 \\
\hline \multicolumn{6}{|l|}{$\begin{array}{ll}\text { Випадкові ситуації та } \\
\text { навантаження, } \\
\text { проявляються рідко та } \\
\text { недовготривалий час }\end{array}$} \\
\hline \begin{tabular}{|l|} 
S- від «Small» - мала \\
Ситуація навантаження та \\
небезпеки \\
щорічно.
\end{tabular} & $\begin{array}{c}2 \text { Малозначний } \\
\text { ризик }\end{array}$ & 3 Малий ризик & 4 Помірний ризик & 5 Прийнятний ризик & $\begin{array}{c}6 \text { Допустимий } \\
\text { ризик }\end{array}$ \\
\hline $\begin{array}{|lr|}\text { M- від «Medium» } \\
\text { середня } \\
\text { Ситуація навантаження та } \\
\text { небезпеки } \\
\text { щосезонно } \\
\end{array}$ & 3 Малий ризик & 4 Помірний ризик & $\begin{array}{c}5 \text { Прийнятний } \\
\text { ризик }\end{array}$ & 6 Допустимий ризик & 7 Значимий ризик \\
\hline \begin{tabular}{|l} 
L - від «Large» - великий \\
Ситуація навантаження та \\
небезпеки \\
щомісячно
\end{tabular} & $\begin{array}{l}4 \text { Помірний } \\
\text { ризик }\end{array}$ & 5 Прийнятний ризик & $\begin{array}{c}6 \text { Допустимий } \\
\text { ризик }\end{array}$ & 7 Значимий ризик & $\begin{array}{c}8 \text { Недопустимий } \\
\text { ризик }\end{array}$ \\
\hline \begin{tabular}{|lr}
$\mathrm{XL}$ - від «eXtra Large» \\
дуже велика \\
Ситуація навантаження та \\
небезпеки & виникає \\
щоденно, & шкідливий \\
вплив & замічено. \\
Навантаження & не \\
стабільне & \\
\end{tabular} & $\begin{array}{c}5 \text { Прийнятний } \\
\text { ризик }\end{array}$ & 6 Допустимий ризик & 7 Значимий ризик & $\begin{array}{c}8 \text { Недопустимий } \\
\text { ризик }\end{array}$ & $\begin{array}{c}9 \text { Максимальний } \\
\text { ризик }\end{array}$ \\
\hline \begin{tabular}{|lr}
$\mathrm{XXL}-$ від & «eXtra \\
Large» & eXtra \\
велика & дуже-дуже \\
Ситуація навантаження та \\
небезпеки \\
щогодинне, \\
шкідливий \\
Навантаження стабільне \\
\end{tabular} & $\begin{array}{c}6 \text { Допустимий } \\
\text { ризик }\end{array}$ & 7 Значимий ризик & $\begin{array}{c}8 \text { Недопустимий } \\
\text { ризик }\end{array}$ & $\begin{array}{c}9 \text { Максимальний } \\
\text { ризик }\end{array}$ & 10 Критичний ризик \\
\hline
\end{tabular}

Об'єктами досліджень стали ризики на робочих місцях оператор лінії розливу, майстер виробництва та водій молокоцистерни, ТОВ «Харківський молочний комбінат».

Порівняльна оцінка ризиків за удосконаленою методикою та за вимогами Міжнародної організації праці

Удосконалену методику оцінки професійних ризиків було випробувано на ТОВ «Харківський молочний комбінат», на робочих місцях оператору лінії розливу, майстер виробництва та водій молокоцистерни та порівняно 3 методикою Міжнародної організації праці.

Використовуючи матриці для оцінки величини професійних ризиків (табл. 2, табл. 3, табл. 4, табл. 5, табл. 6, табл. 7) та методику Міжнародної організації праці [5], були визначені величини ризиків на робочих місцях оператору лінії розливу (табл. 8), майстер виробництва (табл. 9) та водій молокоцистерни (табл. 10).

Таблиця 8 - Визначення величини ризику на робочому місці оператору лінії розливу

\begin{tabular}{|c|c|c|c|c|c|c|c|}
\hline \multirow{2}{*}{$\begin{array}{c}\text { Фактор } \\
\text { небезпеки }\end{array}$} & \multirow[t]{2}{*}{ Опис ситуації: } & \multicolumn{2}{|c|}{ Наслідки } & \multicolumn{2}{|c|}{ Вірогідність } & \multicolumn{2}{|c|}{ Рівень ризику } \\
\hline & & $\begin{array}{c}\text { за удоско- } \\
\text { наленою } \\
\text { методикою }\end{array}$ & $\begin{array}{c}\text { за методикою } \\
\text { Міжнародної } \\
\text { організації праці }\end{array}$ & $\begin{array}{c}\text { за удоскона- } \\
\text { леною } \\
\text { методикою }\end{array}$ & $\begin{array}{c}\text { за методикою } \\
\text { Міжнародної } \\
\text { організації праці }\end{array}$ & $\begin{array}{c}\text { за } \\
\text { удосконаленою } \\
\text { методикою }\end{array}$ & $\begin{array}{c}\text { за методикою } \\
\text { Міжнародної } \\
\text { організації } \\
\text { праці }\end{array}$ \\
\hline 1 & 2 & 3 & 4 & 5 & 6 & 7 & 8 \\
\hline $\begin{array}{l}\text { Виробничій } \\
\text { шум } \\
\text { (імпульсний) }\end{array}$ & \begin{tabular}{|c|} 
Рівень шуму \\
85 дБ(А), діє \\
протягом 8 \\
годин робочої \\
зміни
\end{tabular} & $\begin{array}{c}\text { Легкі } \\
\text { Незручний } \\
\text { стан, } \\
\text { роздрату- } \\
\text { вання }\end{array}$ & $\begin{array}{c}\text { Невеликі (немає } \\
\text { перешкод слуху, } \\
\text { недоліки в } \\
\text { зосередженні } \\
\text { уваги) }\end{array}$ & $\begin{array}{l}\text { XL - від «еXtra } \\
\text { Large» - дуже } \\
\text { велика } \\
\text { Вплив від 100- } \\
\text { 150\% від }\end{array}$ & $\begin{array}{c}\text { Висока (протягом } \\
\text { усієї робочої } \\
\text { зміни, відсутні } \\
\text { засоби захисту }\end{array}$ & $\begin{array}{c}6 \text { Допустимий } \\
\text { ризик }\end{array}$ & $\begin{array}{c}3 \text { Помірний } \\
\text { ризик }\end{array}$ \\
\hline
\end{tabular}




\begin{tabular}{|c|c|c|c|c|c|c|c|}
\hline 1 & 2 & 3 & 4 & 5 & 6 & 7 & 8 \\
\hline & & & & $\begin{array}{c}\text { нормативних } \\
\text { величин }\end{array}$ & & & \\
\hline $\begin{array}{l}\text { Падіння } \\
\text { зв'язку } \\
\text { слизькими } \\
\text { дорогами }\end{array}$ & $\begin{array}{c}\text { Ожеледь на } \\
\text { виробни-чих } \\
\text { дорогах }\end{array}$ & \begin{tabular}{|c|} 
Середні \\
Відсутності від \\
3 до 10 днів. \\
Не довгі \\
серйозні \\
наслідки, \\
постійні \\
слабкі \\
ушкодження: \\
розтягнення \\
м'язів та/ або \\
вивихи \\
\end{tabular} & \begin{tabular}{|c|} 
Середньої \\
важкості \\
Відсутність 3-30 \\
днів. \\
тривалі серйозні \\
наслідки, постійні \\
слабкі \\
пошкодження \\
\end{tabular} & \begin{tabular}{|c|} 
М - від \\
«Mеdium»- \\
середня \\
Стан нещасного \\
випадку \\
щосезонний.
\end{tabular} & \begin{tabular}{|c|} 
Мала \\
Випадкові \\
небезпечні \\
ситуації \\
виникають рідко
\end{tabular} & $\begin{array}{c}6 \text { Допустимий } \\
\text { ризик }\end{array}$ & 2 Малий ризик \\
\hline \begin{tabular}{|l|} 
Постійне \\
положення \\
сидячі
\end{tabular} & $\begin{array}{c}\text { Постійна } \\
\text { сидяча робота } \\
\text { викликає } \\
\text { напругу } \\
\text { і втому м'язів }\end{array}$ & \begin{tabular}{|c|} 
Довго-тривалі \\
не серйозні, \\
постійні \\
впливи, \\
постійна \\
незначна \\
шкода, повто- \\
рювальна \\
відсутність
\end{tabular} & \begin{tabular}{|c} 
Середньої \\
важкості \\
Довготривалі \\
серйозні, постійні \\
впливи, постійна \\
слабка випадкова \\
відсутність
\end{tabular} & \begin{tabular}{|c|} 
XXL - від «еXtra \\
еXtra Large»- \\
дуже-дуже \\
велика \\
Ситуація \\
небезпеки та \\
навантаження \\
щогодинне \\
(постійне) \\
\end{tabular} & $\begin{array}{c}\text { Висока } \\
\text { Ситуації } \\
\text { небезпеки і } \\
\text { навантаження } \\
\text { постійні }\end{array}$ & $\begin{array}{c}8 \text { Недопустимий } \\
\text { ризик }\end{array}$ & $\begin{array}{c}4 \text { Значний } \\
\text { ризик }\end{array}$ \\
\hline $\begin{array}{l}\text { Миючі та } \\
\text { дезінфікуючі } \\
\text { засоби, луги }\end{array}$ & \begin{tabular}{|c} 
Вдихання \\
протягом \\
робочого дня \\
парів миючих \\
та \\
дезінфікуючих \\
засобів, лугів, \\
їх кількість не \\
перевищує \\
$60 \%$ від ГДК
\end{tabular} & \begin{tabular}{|c|} 
Середні \\
Не постійна \\
короткотрива \\
ла легка \\
шкода, ознаки \\
проблеми з \\
диханням
\end{tabular} & \begin{tabular}{|c|} 
Середньої \\
важкості \\
Довготривалі \\
серйозні впливи
\end{tabular} & \begin{tabular}{|c|} 
L- від «Large» \\
- великий \\
Хімічні \\
речовини \\
застосо-вуються \\
щомісячно. İx \\
вміст від 50- \\
100\% від норма- \\
тивного \\
значення
\end{tabular} & \begin{tabular}{|c|} 
Середня \\
Хімічні речовини \\
застосо-вуються \\
часто, їх вміст \\
помірні
\end{tabular} & $\begin{array}{c}6 \text { Допустимий } \\
\text { ризик }\end{array}$ & $\begin{array}{l}3 \text { Помірний } \\
\text { ризик }\end{array}$ \\
\hline |ГРВ| & $\begin{array}{c}\text { Щосезонне } \\
\text { зараження від } \\
\text { іншого } \\
\text { працівника } \\
\text { ГРВІ }\end{array}$ & $\mid \begin{array}{c}\text { Легкі } \\
\text { Легко мінливе } \\
\text { респіра-торні } \\
\text { захво- } \\
\text { рювання }\end{array}$ & - & \begin{tabular}{|c|} 
М - від \\
«Mеdium»- \\
середня. \\
Біологічні \\
агенти, мікро- \\
організми \\
щосезонно \\
контактують з \\
організмом \\
працівника. Ïх \\
кількість від 25- \\
50\% від норма- \\
тивного \\
значення \\
знчен
\end{tabular} & - & $\begin{array}{l}4 \text { Помірний } \\
\text { ризик }\end{array}$ & - \\
\hline $\begin{array}{l}\text { Тривале } \\
\text { неспання }\end{array}$ & \begin{tabular}{|c} 
Під час \\
робочої зміни \\
безпе- \\
рервний стан \\
неспання
\end{tabular} & \begin{tabular}{|c|} 
Легкі \\
Роздра- \\
тованість, \\
низька \\
здатність \\
концентрації \\
та роботи, \\
мала \\
відсутність \\
\end{tabular} & \begin{tabular}{|c|} 
Середньої \\
важкості \\
низька здатність \\
концентрації і \\
роботи, \\
безпорадність і \\
занепокоєння, \\
відсутності, що \\
повторюються \\
\end{tabular} & \begin{tabular}{|c|} 
L- від «Large» \\
- великий \\
Ситуація \\
навантаження \\
та небезпеки \\
виникає \\
щомісячно
\end{tabular} & $\begin{array}{c}\text { Середня } \\
\text { Ситуація } \\
\text { небезпеки і } \\
\text { навантаження } \\
\text { виникає постійно } \\
\text { або на деякий час }\end{array}$ & $\begin{array}{c}5 \text { Прийнятний } \\
\text { ризик }\end{array}$ & $\begin{array}{l}3 \text { Помірний } \\
\text { ризик }\end{array}$ \\
\hline
\end{tabular}

Таблиця 9- Визначення величини ризику на робочому місці майстра виробництва

\begin{tabular}{|c|c|c|c|c|c|c|c|}
\hline \multirow[b]{2}{*}{$\begin{array}{c}\text { Фактор } \\
\text { небезпеки }\end{array}$} & \multirow[b]{2}{*}{ Опис ситуації: } & \multicolumn{2}{|c|}{ Наслідки } & \multicolumn{2}{|c|}{ Вірогідність } & \multicolumn{2}{|c|}{ Рівень ризику } \\
\hline & & $\begin{array}{c}\text { за удоско- } \\
\text { наленою } \\
\text { методикою }\end{array}$ & $\begin{array}{c}\text { за методикою } \\
\text { Міжнародної } \\
\text { організації } \\
\text { праці }\end{array}$ & $\begin{array}{c}\text { за удоскона- } \\
\text { леною } \\
\text { методикою }\end{array}$ & $\begin{array}{c}\text { за методикою } \\
\text { Міжнародної } \\
\text { організації праці }\end{array}$ & $\begin{array}{c}\text { за } \\
\text { удосконаленою } \\
\text { методикою }\end{array}$ & $\begin{array}{c}\text { за методикою } \\
\text { Міжнародної } \\
\text { організації } \\
\text { праці } \\
\end{array}$ \\
\hline 1 & 2 & 3 & 4 & 5 & 6 & 7 & 8 \\
\hline $\begin{array}{l}\text { Виробничій } \\
\text { шум } \\
\text { (імпульсний) } \\
\end{array}$ & \begin{tabular}{|c|} 
Рівень шуму \\
121 дБ(А), діє \\
протягом 8 \\
\end{tabular} & $\begin{array}{l}\text { Середні } \\
\text { Тривалі } \\
\text { серйозні }\end{array}$ & $\begin{array}{l}\text { Середньої } \\
\text { важкості }\end{array}$ & $\begin{array}{c}\text { XXL - від «еXtra } \\
\text { eXtra Large» - }\end{array}$ & Висока & $\begin{array}{c}8 \text { Недопустимий } \\
\text { ризик }\end{array}$ & $\begin{array}{c}4 \text { Значимий } \\
\text { ризик }\end{array}$ \\
\hline
\end{tabular}




\begin{tabular}{|c|c|c|c|c|c|c|c|}
\hline 1 & 2 & 3 & 4 & 5 & 6 & 7 & 8 \\
\hline & $\begin{array}{c}\text { годин робочої } \\
\text { зміни }\end{array}$ & \begin{tabular}{|c|} 
впливи, тривала \\
легка шкода, \\
перешкоди \\
органам слуху.
\end{tabular} & \begin{tabular}{|c|} 
Тривалі \\
серйозні \\
впливи, тривала \\
легка шкода, \\
перешкоди \\
органам слуху
\end{tabular} & $\begin{array}{c}\text { дуже-дуже } \\
\text { велика } \\
\text { Вплив понад } \\
150 \% \text { від } \\
\text { нормативних } \\
\text { величин } \\
\end{array}$ & $\begin{array}{c}\text { Вище від } \\
\text { нормативного } \\
\text { значення }\end{array}$ & & \\
\hline \begin{tabular}{|l} 
Падіння \\
зв'язку \\
слизькою \\
підлогою
\end{tabular} & $\begin{array}{c}\text { у Мокра та } \\
\text { слизька } \\
\text { підлога у } \\
\text { виро-бничому } \\
\text { приміщені }\end{array}$ & \begin{tabular}{|c} 
Тяжкі \\
Відсутність на \\
роботі \\
від 10 до 90 \\
робочих днів. \\
Довготривалі \\
серйозні \\
наслідки, \\
постійні сильні \\
ушкодження: \\
наслідки після \\
тяжких \\
переломі
\end{tabular} & \begin{tabular}{|c|} 
Середньої \\
важкості \\
Відсутності 3 30 \\
днів. \\
Тривалі \\
серйозні \\
наслідки, \\
постійні слабкі \\
пошкодження: \\
переломи
\end{tabular} & $\mid \begin{array}{c}\text { S- від «Small» } \\
\text { - мала } \\
\text { Стан нещасного } \\
\text { випадку } \\
\text { щорічний. } \\
\text { Нещасний } \\
\text { випадок був } \\
\text { майже } \\
\text { близьким }\end{array}$ & $\begin{array}{c}\text { Середня } \\
\text { Стан нещасного } \\
\text { випадку } \\
\text { щоденний. } \\
\text { Нещасний } \\
\text { випадок був } \\
\text { близький }\end{array}$ & $\begin{array}{c}5 \text { Прийнятний } \\
\text { ризик }\end{array}$ & $\begin{array}{c}3 \text { Помірний } \\
\text { ризик }\end{array}$ \\
\hline $\begin{array}{|lr|}\text { Шляхи } & \text { руху, } \\
\text { виходи } & \text { і } \\
\text { еляхи } \\
\text { евакуації } \\
\end{array}$ & $\begin{array}{c}\text { Шляхи руху } \\
\text { слизькі, в } \\
\text { деяких місцях } \\
\text { та евакуаційні } \\
\text { виходи } \\
\text { замкнуті }\end{array}$ & $\begin{array}{c}\text { Легкі } \\
\text { Короткотривалі } \\
\text { незначні } \\
\text { впливи, не } \\
\text { постійна і } \\
\text { незначна } \\
\text { шкода, } \\
\text { випадкова } \\
\text { відсутність }\end{array}$ & $\begin{array}{c}\text { Легкі } \\
\text { Непри-ємність, } \\
\text { роздра-тування, } \\
\text { наванта-ження } \\
\text { що проходить }\end{array}$ & \begin{tabular}{|c|}
$\mathrm{XXL}$ - від «еXtra \\
еXtra Large»- \\
дуже-дуже \\
велика \\
Ситуація \\
небезпеки та \\
наванта-ження \\
щогодинне \\
(постійне) \\
\end{tabular} & $\begin{array}{c}\text { Середня } \\
\text { Ситуації } \\
\text { небезпеки і } \\
\text { навантаження } \\
\text { щоденні }\end{array}$ & $\begin{array}{c}7 \text { Значимий } \\
\text { ризик }\end{array}$ & 2 Малий ризик \\
\hline \begin{tabular}{|l} 
Миючі та \\
дезінфікуючі \\
засоби, луги
\end{tabular} & $\begin{array}{c}\text { Вдихання } \\
\text { протягом } \\
\text { робочого дня } \\
\text { парів миючих } \\
\text { та } \\
\text { дезінфікуючих } \\
\text { засобів, лугів, } \\
\text { їх кількість } \\
120 \% \text { від ГдК }\end{array}$ & \begin{tabular}{|c|} 
Не постійна \\
короткотривала \\
легка шкода, \\
признаки \\
проблеми з \\
диханням, \\
хімічні опіки \\
дихальних \\
шляхів 1-2 \\
ступеня
\end{tabular} & \begin{tabular}{|c} 
Середньої \\
важкості \\
Довготривалі \\
серйозні \\
впливи, \\
постійна легка \\
шкода
\end{tabular} & \begin{tabular}{|c|}
$\mathrm{XL}$ - від «еXtra \\
Large» - дуже \\
велика \\
Хімічні \\
речовини \\
застосовуються \\
щоденно. \\
Проявляються \\
ознаки їх \\
впливу, їх вміст \\
від 100-150\% \\
від \\
нормативного \\
значення \\
\end{tabular} & $\begin{array}{c}\text { Висока } \\
\text { 3'являються } \\
\text { ознаки їх впливу }\end{array}$ & $\begin{array}{c}7 \text { Значимий } \\
\text { ризик }\end{array}$ & $\begin{array}{c}4 \text { Значимий } \\
\text { ризик }\end{array}$ \\
\hline $\begin{array}{l}\text { Золотистий } \\
\text { стафілокок }\end{array}$ & $\begin{array}{c}\text { Постійна } \\
\text { можливість } \\
\text { зараження } \\
\text { золотистим } \\
\text { стафіло- } \\
\text { коком, вміст } \\
\text { 10\% від } \\
\text { норма- } \\
\text { тивного } \\
\text { значення }\end{array}$ & $\begin{array}{c}\text { Середні } \\
\text { Не постійна } \\
\text { коротко- } \\
\text { тривала легка } \\
\text { шкода, } \\
\text { інтоксикація } \\
\text { спричинена } \\
\text { продуктами } \\
\text { життє- } \\
\text { діяльності } \\
\text { біологічних } \\
\text { агентів }\end{array}$ & - & \begin{tabular}{|c|} 
XS - від «еXtra \\
Small» - дуже \\
мала. \\
Біологічні \\
агенти, макро- \\
та мікро- \\
організми \\
майже не \\
контактують з \\
організмом \\
працівника. Ïх \\
кількість дуже \\
низька, до $10 \%$ \\
від норма- \\
тивного \\
значення. \\
\end{tabular} & - & 3 Малий ризик & - \\
\hline Поспіх & $\begin{array}{c}\text { Постійний } \\
\text { поспіх або } \\
\text { постійно } \\
\text { повторювані } \\
\text { піки поспіху }\end{array}$ & $\begin{array}{c}\text { Середні } \\
\text { Нервовий зрив, } \\
\text { постійні, сильні } \\
\text { стреси, паніка, } \\
\text { зане-покоєння, }\end{array}$ & $\mid \begin{array}{c}\text { Середньої } \\
\text { важкості } \\
\text { низька здатність } \\
\text { концентрації і } \\
\text { роботи, }\end{array}$ & \begin{tabular}{|c|} 
XXL - від «eXtra \\
eXtra Large» - \\
дуже-дуже \\
велика
\end{tabular} & $\begin{array}{c}\text { Середня } \\
\text { Ситуація } \\
\text { небезпеки і } \\
\text { навантаження }\end{array}$ & $\begin{array}{c}8 \text { Недопустимий } \\
\text { ризик }\end{array}$ & $\begin{array}{c}3 \text { Помірний } \\
\text { ризик }\end{array}$ \\
\hline
\end{tabular}




\begin{tabular}{|c|c|c|c|c|c|c|c|}
\hline 1 & 2 & 3 & 4 & 5 & 6 & 7 & 8 \\
\hline & $\begin{array}{c}\text { протягом } \\
\text { робочої зміни }\end{array}$ & $\begin{array}{c}\text { повторювальна } \\
\text { відсутність }\end{array}$ & \begin{tabular}{|c} 
безпо-радність і \\
зане-покоєння, \\
що повто- \\
рюються \\
відсутності
\end{tabular} & $\begin{array}{c}\text { Ситуація } \\
\text { наванта-ження } \\
\text { та небезпеки } \\
\text { виникає } \\
\text { щогодинне, } \\
\text { великий } \\
\text { шкідливий } \\
\text { вплив. Наванта- } \\
\text { ження стабільне }\end{array}$ & $\begin{array}{c}\text { виникає постійно } \\
\text { або на } \\
\text { деякий час }\end{array}$ & & \\
\hline
\end{tabular}

Таблиця 10 - Визначення величини ризику на робочому місці водія молокоцистерни

\begin{tabular}{|c|c|c|c|c|c|c|c|}
\hline \multirow[b]{2}{*}{$\begin{array}{c}\text { Фактор } \\
\text { небезпеки }\end{array}$} & \multirow[b]{2}{*}{ Опис ситуації: } & \multicolumn{2}{|c|}{ Наслідки } & \multicolumn{2}{|c|}{ Вірогідність } & \multicolumn{2}{|c|}{ Рівень ризику } \\
\hline & & $\begin{array}{c}\text { за удоско- } \\
\text { наленою } \\
\text { методикою }\end{array}$ & $\begin{array}{c}\text { за методикою } \\
\text { Міжнародної } \\
\text { організації праці }\end{array}$ & $\begin{array}{l}\text { за удоскона- } \\
\text { леною } \\
\text { методикою }\end{array}$ & $\begin{array}{c}\text { за методикою } \\
\text { Міжнародної } \\
\text { організації праці }\end{array}$ & $\begin{array}{c}\text { за } \\
\text { удосконалено } \\
\text { ю методикою }\end{array}$ & $\begin{array}{c}\text { за методикою } \\
\text { Міжнародної } \\
\text { організації } \\
\text { праці }\end{array}$ \\
\hline
\end{tabular}

\begin{tabular}{|c|c|c|c|c|c|c|c|}
\hline 1 & 2 & 3 & 4 & 5 & 6 & 7 & 8 \\
\hline Вібрація & $\begin{array}{c}\text { Рівень вібрації } \\
116 \text { дб } \\
\text { протягом } 8 \\
\text { годин робочої } \\
\text { зміни }\end{array}$ & \begin{tabular}{|c|} 
Середні \\
Тривалі \\
серйозні \\
впливи, \\
тривала легка \\
шкода \\
\end{tabular} & \begin{tabular}{|c|} 
Середньої \\
важкості \\
Тривалі серйозні \\
впливи, тривала \\
легка шкода
\end{tabular} & $\begin{array}{l}\text { XL - від «еXtra } \\
\text { Large» - дуже } \\
\text { велика } \\
\text { Вплив від 100- } \\
\text { 150\% від } \\
\text { нормативних } \\
\text { величин }\end{array}$ & $\begin{array}{c}\text { Висока } \\
\text { Вище } \\
\text { нормативних } \\
\text { значень }\end{array}$ & $\begin{array}{c}7 \text { Значимий } \\
\text { ризик }\end{array}$ & $\begin{array}{c}4 \text { Значимий } \\
\text { ризик }\end{array}$ \\
\hline $\begin{array}{l}\text { Падіння } \\
\text { висоти }\end{array}$ & $3 \begin{array}{c}\text { Падіння з } \\
\text { висоти під час } \\
\text { обслу- } \\
\text { говування } \\
\text { моло- } \\
\text { коцистерни }\end{array}$ & $\mid \begin{array}{c}\text { Ката-строфічні } \\
\text { Відсутності } \\
\text { більше } 90 \\
\text { днів. } \\
\text { Постійна } \\
\text { непрацездатні } \\
\text { сть, інва- } \\
\text { лідність або } \\
\text { смерть }\end{array}$ & \begin{tabular}{|c|} 
Важкі \\
Відсутність на \\
роботі \\
$>30$ робочих днів \\
Постійна \\
неробото- \\
здатність, смерть
\end{tabular} & \begin{tabular}{|c|} 
XS - від «еXtra \\
Small»- дуже \\
мала \\
Випадкові та \\
небезпечні \\
ситуації \\
виникають рідко
\end{tabular} & $\begin{array}{c}\text { Мала } \\
\text { Випадкові } \\
\text { небезпечні } \\
\text { ситуації } \\
\text { виникають рідко }\end{array}$ & $\begin{array}{c}5 \text { Прийнятний } \\
\text { ризик }\end{array}$ & $\begin{array}{c}3 \text { Помірний } \\
\text { ризик }\end{array}$ \\
\hline $\begin{array}{l}\text { Можливість } \\
\text { змінювати } \\
\text { робочі } \\
\text { положення }\end{array}$ & \begin{tabular}{|c} 
Відсутня \\
можливість \\
змінювати \\
робочі пози, \\
постійна \\
сидяча робота \\
під час \\
молоко- \\
перевезенні
\end{tabular} & \begin{tabular}{|c|} 
Середні \\
Довго-тривалі \\
не серйозні, \\
постійні \\
впливи, \\
постійна \\
незначна \\
шкода, повто- \\
рювальна \\
відсутність \\
\end{tabular} & \begin{tabular}{|c|} 
Середньої \\
важкості \\
Довготривалі \\
серйозні, постійні \\
впливи, постійний \\
слабка шкода, \\
випадкова \\
відсутність
\end{tabular} & $\begin{array}{l}\text { XXL-від «еXtra } \\
\text { еXtra Large»- } \\
\text { дуже-дуже } \\
\text { велика } \\
\text { Ситуація } \\
\text { небезпеки та } \\
\text { навантаження } \\
\text { щогодинне } \\
\text { (постійне) }\end{array}$ & $\begin{array}{c}\text { Середня } \\
\text { Ситуації } \\
\text { небезпеки і } \\
\text { навантаження } \\
\text { щоденні }\end{array}$ & \begin{tabular}{|c|} 
\\
Недопустимий \\
ризик
\end{tabular} & $\begin{array}{c}3 \text { Помірний } \\
\text { ризик }\end{array}$ \\
\hline Пари палива & $\begin{array}{c}\text { Можли-вість } \\
\text { вибуху та } \\
\text { пожежі } \\
\text { протягом } \\
\text { робочого дня } \\
\text { парів палива, } \\
\text { їх кількість до } \\
\text { 100\% від гДК } \\
\end{array}$ & $\begin{array}{c}\text { Ката-строфічні } \\
\text { пожежа, } \\
\text { вибух, смерть }\end{array}$ & Важкі & $\begin{array}{c}\mathrm{L}-\text { від «Large»- } \\
\text { великий } \\
\text { Хімічні речовини } \\
\text { застосо-вуються } \\
\text { щомісячно. Їх } \\
\text { вміст від 50-100\% } \\
\text { від нормативного } \\
\text { значення } \\
\end{array}$ & $\begin{array}{c}\text { Середня } \\
\text { Хімічні речовини } \\
\text { застосо-вуються } \\
\text { часто. їх вміст } \\
\text { помірний }\end{array}$ & $\begin{array}{c}8 \\
\text { Недопустимий } \\
\text { ризик }\end{array}$ & $\begin{array}{c}4 \text { Значимий } \\
\text { ризик }\end{array}$ \\
\hline COVID-19 & $\begin{array}{c}\text { Зараження від } \\
\text { інших } \\
\text { працівників } \\
\text { COVID-19 на } \\
\text { підпри-ємстві, } \\
\text { до 10\% від } \\
\text { норма- } \\
\text { тивного } \\
\text { значення }\end{array}$ & $\mid \begin{array}{c}\text { Ката-строфічні } \\
\text { Постійні } \\
\text { серйозні } \\
\text { впливи COVID-- } \\
19\end{array}$ & - & \begin{tabular}{|c|} 
XS - від «еXtra \\
Small» - дуже \\
мала. \\
Біологічні агенти, \\
макро- та \\
мікроорганізми \\
майже не \\
контактують з \\
організмом \\
працівника. Ïх \\
кількість дуже \\
\end{tabular} & - & $\begin{array}{c}5 \text { Прийнятний } \\
\text { ризик }\end{array}$ & - \\
\hline
\end{tabular}




\begin{tabular}{|c|c|c|c|c|c|c|c|}
\hline 1 & 2 & 3 & 4 & 5 & 6 & 7 & 8 \\
\hline & & & & $\begin{array}{c}\text { низька, до } 10 \% \\
\text { від нормативного } \\
\text { значення. }\end{array}$ & & & \\
\hline $\begin{array}{l}\text { Відсутність } \\
\text { перспективи } \\
\text { просуванні }\end{array}$ & \begin{tabular}{|c|} 
водій не має \\
вожливості \\
підвищувати \\
свою квалі- \\
фікації та \\
самовдоскона \\
люватися
\end{tabular} & \begin{tabular}{|c} 
Тяжкі \\
Безпо- \\
радність, \\
мінлива, \\
сезонна \\
депресія, не \\
постійна, але \\
велика \\
відсутність
\end{tabular} & \begin{tabular}{|c|} 
Важкі \\
Безнадія, сильна \\
депресія, постійні \\
відсутності
\end{tabular} & \begin{tabular}{|c}
$\mathrm{XL}-$ від «еXtra \\
Large» - дуже \\
велика \\
Ситуація \\
навантаження та \\
небезпеки \\
виникає \\
щоденно, \\
шкідливий вплив \\
замічено. \\
Навантаження не \\
стабільне
\end{tabular} & \begin{tabular}{|c|} 
Середня \\
Ситуація \\
небезпеки і \\
навантаження \\
виникає постійно \\
або на \\
деякий час
\end{tabular} & \begin{tabular}{|c|}
8 \\
Недопустимий \\
ризик
\end{tabular} & $\begin{array}{c}4 \text { Значимий } \\
\text { ризик }\end{array}$ \\
\hline
\end{tabular}

Проаналізувавши отримані результати згідно з таблиці 9 та таблиці 10, було встановлено, що удосконалена методика визначення величини професійного ризику $\epsilon$ адекватною і більш точною ніж методика Міжнародної організації праці. Тому що вона надає можливість більш точно визначити величину настання події (ризику), врахувати значимість наслідків та отримати рейтинг ризиків, які притаманні для певного робочого місць. Удосконалена методика дає чітко визначити ризики, які спричинені біологічними факторами небезпеки, а також врахувати фактори катастрофічні наслідки, надзвичайні ситуації такі як пожежа, вибух, аварія на виробництві. Отриманий рейтинг ризиків на робочому місці дає можливість у майбутньому приділити більшу увагу більш значимим ризикам та невідкладно запровадити заходи з їх попередження, а також відібрати незначних ризиків, які потрібно знехтувати.

\section{Заходи 3 управління професійними ризиками}

Для підвищення рівня охорони праці були запропоновані та впровадженні заходи 3 управління професійними ризиками (табл. 11).

Таблиця 11 - Заходи з управління професійними ризиками

\begin{tabular}{|l|l|}
\hline \multicolumn{1}{|c|}{ Фактор небезпеки } & \multicolumn{1}{|c|}{ Заходи з управління професійними ризиками } \\
\hline $\begin{array}{l}\text { Виробничій шум } \\
\text { (імпульсний) }\end{array}$ & $\begin{array}{l}\text { Передбачити індивідуальний захист для вух або змонтувати шумопоглинаючи } \\
\text { панелі }\end{array}$ \\
\hline $\begin{array}{l}\text { Падіння у зв'язку 3 } \\
\text { слизькою дорогами }\end{array}$ & $\begin{array}{l}\text { Своєчасно посипати дороги фрикційною сумішшю та використовувати реагенти } \\
\text { для видалення ожеледі }\end{array}$ \\
\hline $\begin{array}{l}\text { Постійне положення } \\
\text { сидячі }\end{array}$ & $\begin{array}{l}\text { Запровадити в індивідуальному графіку роботи, раз на } 55 \text { хвилин робити } \\
\text { розминку, присідання та перерву до 15 хвилин }\end{array}$ \\
\hline $\begin{array}{l}\text { Миючі } \\
\text { дезінфікуючі засоби, та } \\
\text { луги }\end{array}$ & $\begin{array}{l}\text { Після кожного використання миючих та дезінфікуючих засобів, лугів } \\
\text { проврювати виробничі приміщення, робити прибирання після робочої зміни. } \\
\text { Використовувати респіратори }\end{array}$ \\
\hline ГРВІ & $\begin{array}{l}\text { Передбачити щеплення для працівників. Двічі на день в приміщенні повинна } \\
\text { проводитися вологе прибирання з звичайними дезінфікуючими засобами. } \\
\text { Кожну годину кімнату робити провітрювання. Запровадити масковий режим під } \\
\text { час карантину, видавати миючі та антисептичні засоби. Контролювати перед } \\
\text { початком роботи стан здоров'я всіх працівників }\end{array}$ \\
\hline $\begin{array}{l}\text { Тривале неспання } \\
\text { Бажано переглянути зміни працюючих. Не залишати працівників самиху нічний } \\
\text { час, передбачити змогу заміни працюючого, при цьому в кімнаті для відпочинку } \\
\text { передбачити ліжко }\end{array}$ \\
\hline $\begin{array}{l}\text { Падіння у зв'язку з } \\
\text { слизькою підлогою }\end{array}$ & $\begin{array}{l}\text { Забезпечити працівників фрикційним взутям та вчасно прибирати від води } \\
\text { підлогу }\end{array}$ \\
\hline $\begin{array}{l}\text { Шляхи руху, виходи і } \\
\text { шляхи евакуації }\end{array}$ & $\begin{array}{l}\text { Змонтувати гумове покриття, вчасно прибирати підлогу від зайвих предметів, } \\
\text { відчинити евакуаційні виходи та надати до них вільний доступ. }\end{array}$ \\
\hline
\end{tabular}




\begin{tabular}{|c|c|}
\hline Фактор небезпеки & Заходи з управління професійними ризиками \\
\hline $\begin{array}{l}\text { Золо } \\
\text { стафі }\end{array}$ & $\begin{array}{l}\text { Мити руки та захищати відкрити рани, намагатися користуватися своїм } \\
\text { засобами індивідуально гігієни та кашляти (чихати) в зігнути лікоть. Всім } \\
\text { працівникам вчасно проходити медичний огляд }\end{array}$ \\
\hline Поспіх & $\begin{array}{l}\text { Організувати робочий день, так щоб у працівника було достатньо часу для } \\
\text { реалізації поставлених задач }\end{array}$ \\
\hline Вібрація & Модернізувати автоцистерну, передбачити ергономічні та амортизуючи сидіння \\
\hline Падіння & $\begin{array}{l}\text { Передбачити своєчасне використання страхового поясу та встановити } \\
\text { перешкоду }\end{array}$ \\
\hline $\begin{array}{l}\text { Можливість } \\
\text { змінювати робочі } \\
\text { положення }\end{array}$ & $\begin{array}{l}\text { Робити зупинку та виходити з автомобіля для розминки та перерви. } \\
\text { Передбачити обов'язкові присідання }\end{array}$ \\
\hline Пари палива & $\begin{array}{l}\text { Організовувати регулярне технічне діагностування, проводити планово- } \\
\text { попереджувальні ремонти, експлуатувати примусову вентиляцію у } \\
\text { приміщеннях з автоцистернами }\end{array}$ \\
\hline COVID-19 & $\begin{array}{l}\text { Двічі на день в приміщенні повинна проводитися вологе прибирання з } \\
\text { звичайними дезінфікуючими засобами. Кожну годину кімнату робити } \\
\text { провітрювання. Запровадити масковий режим під час карантину, видавати } \\
\text { маски, миючі та антисептичні засоби. Контролювати перед початком роботи } \\
\text { стан здоров'я всіх працівників. Робити температурний безконтактний скринінг. } \\
\text { Працівникам похилого віку надати можливість піти у відпустку }\end{array}$ \\
\hline $\begin{array}{l}\text { Відсутність } \\
\text { перспективи } \\
\text { просуванні }\end{array}$ & $\begin{array}{l}\text { Передбачити підвищення кваліфікації працівників, отримання за рахунок } \\
\text { підприємства вищої освіти, проведення регулярного навчання працівників }\end{array}$ \\
\hline
\end{tabular}

\section{Висновки}

1. Було проаналізовано існуючі методи оцінки професійних ризиків, з яких було обрано найбільш точний та адекватний метод оцінки професійних ризиків Міжнародної організації праці.

2. Розроблено матрицю для оцінки величини професійного ризику та удосконалено методику Міжнародної організації праці для оцінки професійного ризику. Було розроблено п'ять рівнів серйозності наслідків, п'ять рівнів вірогідності шкоди для працівника та величину ризику від мінімального значення 1 (знехтуваний ризик) до максимального - 10 (критичний ризик).

3. Для визначення величини ризиків, які заподіяні фізичними, хімічними, біологічними факторами небезпеки, частотою виникнення нещасного випадку, недоліками в ергономіці та психологічними перенавантаженнями було розроблено критерії для матриць. Наслідки заподіяної шкоди можуть бути: незначні, легкі, середні, тяжкі та катастрофічні.

4. Удосконалена методика дає можливість врахувати катастрофічні наслідки, які можуть настати під час надзвичайної ситуації, такої як пожежа, вибух, аварія, катастрофа та ін. Вірогідність професійних ризиків може бути: XS - від «eXtra Small» - дуже мала, S - від «Small» - мала, M - від «Medium» - середня, L - від «Large» - велика, XL - від «еXtra Large» - дуже велика та XXL - від «eXtra eXtra Large» - дуже-дуже велика.

5. Удосконалена методика визначає: знехтуваний, малозначний, малий, помірний, прийнятний, допустимий, значимий, недопустимий, максимальний та критичний ризик.

6. Удосконалену методику оцінки професійних ризиків було випробувано на молочному комбінаті. Було встановлено адекватність і точність результатів визначення величини професійного ризику удосконаленої методики порівняно 3 результатами існуючої. Визначено ранг ризиків на трьох робочих місцях.

7. Для підвищення рівня охорони праці були запропоновані та впровадженні заходи з управління професійними ризиками. 


\section{Список використаних джерел}

1. Ristić D., Stanković M., Savić S. Risk assessment matrices // Proceeding of 11th International Conference «Dependability and quality management». 2008. P. 580-587.

2. Stankovic M., Stanković V. Comparative analysis of methods for risk assessment - "Kinney" and "Auva" // Safety Engineering. 2013. P. 129-136.

3. Федорец А. Г. Методические основы количественного оценивания производственных рисков // Энергобезопасность и энергосбережение. №2. 2008. URL: https://cyberleninka.ru/article/n/metodiche skie-osnovy-kolichestvennogo-otsenivaniyaproizvodstvennyh-riskov.

4. ELMERI. Пособие по наблюдению за условиями труда на рабочем месте в промышленности. Институт профессионального здравоохранения Финляндии, Управление по охране труда при Министерстве социального обеспечения и здравоохранения Финляндии. 24 c. URL: http://base.safework.ru/safework?navigator \&spack=110listid\%3D010000000100\%26listp os\%3D2\%26lsz\%3D9\%26nd\%3D444400008\% 26nh\%3D0\%26.

5. Мерви Муртонен. Оценка рисков на рабочем месте - практическое пособие: серия Охрана труда: Международный опыт. Выпуск 1. Субрегиональное бюро МОТ для стран Европы и Центральной Азии. 2007. 64 c. URL: http://www.studmed.ru/ murtonen-m-ocenka-riskov-na-rabochemmeste-prakticheskoe-posobie-vypusk-1opyt-finlyandii_e79e78e5257.html\#.

6. Тимофеева С. С. Современные методы оценки профессиональных рисков и их значение в системе управления охраной труда // Охрана труда и промышленная безопасность. №1 (1). 2016. С. 14-24.

7. Рогач Ю. П. Практичні підходи по оцінці ризику нещасних випадків на підприємствах АПК. Наукове товариство Smart and Young. №7. 2016. С. 76-81.

8. Бочковський А. П. «Людський фактор» та ризик виникнення небезпек: випадковість чи закономірність. Юридична література. 2015. 137 c.

9. Бочковський А. П. Теоретичні аспекти універсалізації оцінки професійного ризику в системах управління охороною праці. Вісник ЛДУ БЖД. №14. 2016. С. 134-151.

10. Zaikina D. Development of the unified technique for the monitoring of occupational hazards at Kryvbas mining enterprises (Ukraine). Eastern-European Journal of Enterprise Technologies. V. 3. №10 (87). 2017. P. 18-27.

11. Колобиліна О., Кравцова С. Розробляння комплексної методики ідентифікації небезпек та оцінки професійних ризиків в умовах виробничої діяльності підприємств. Стандартизація сертифікація якість. №4. 2013. С. 32-37.

\section{Повышение уровня охраны труда и усовершенствование методики международной организации труда для оценки профессиональных рисков}

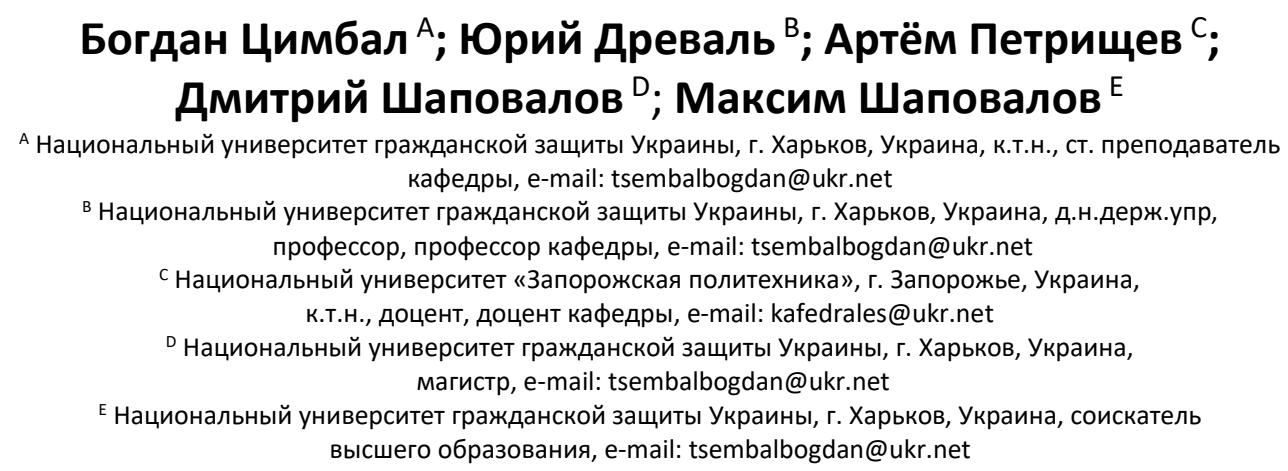




\begin{abstract}
Аннотация
В данной работе представлен анализ существующих методик оценки профессиональных рисков. Было разработано матрицу для оценки величины профессионального риска и усовершенствована методика Международной организации труда для оценки профессионального риска. Было разработано пять уровней серьезности последствий, пять уровней вероятности ущерба для работника и величину риска от минимального значения 1 (пренебрежённый риск) до максимального - 10 (критический риск). Для определения величины рисков, которые причинены физическими, химическими, биологическими факторами опасности, частотой возникновения несчастного случая, недостатками в эргономике и психологической перегрузкой были разработаны критерии для матриц. Последствия причиненного ущерба могут быть: незначительные, легкие, средние, тяжелые и катастрофические. Усовершенствованная методика даёт возможность учесть катастрофические последствия, которые могут наступить при чрезвычайной ситуации, такой как пожар, взрыв, авария, катастрофа и др. Вероятность профессиональных рисков может быть: XS - от «eXtra Small» - очень малая, S - от «Small» - малая, M - от «Medium» - средняя, L - от "Large» - большая, XL - от «eXtra Large» очень большая и XXL - от «eXtra eXtra Large» - очень-очень велика. Усовершенствованная методика определяет: пренебрежённый, незначительный, малый, умеренный, приемлемый, допустимый, значимый, недопустим, максимальный и критический риск. Усовершенствованную методику оценки профессиональных рисков было испытано на молочном комбинате. Было установлено адекватность и точность результатов определения величины профессионального риска, усовершенствованной методики по сравнению с результатами существующей. Для повышения уровня охраны труда были предложены и внедрены мероприятия по управлению профессиональными рисками.
\end{abstract}

Ключевые слова: Международная организация труда, методика оценки профессиональных рисков, экспертный метод, пренебрежённый риск, принимаемый риск, катастрофический риск, допустимый риск, молочный комбинат, мероприятия по охране труда, факторы опасности.

\title{
Raising of the labor protection level and improving the international labour organization methodology for the occupational hazards assessing
}

\author{
Bohdan Tsymbal ${ }^{\text {A }}$; Yuriy Dreval ${ }^{\mathrm{B}}$; Arte, Petryshchev ${ }^{\mathrm{C}}$; \\ Dmytro Shapovalov ${ }^{D}$; Maksym Shapovalov ${ }^{\mathrm{E}}$ \\ A National University of Civil Defence of Ukraine, Kharkov, Ukraine, PhD, Senior Lecturer \\ Departments, e-mail: tsembalbogdan@ukr.net \\ B National University of Civil Defence of Ukraine, Kharkov, Ukraine, Doctor of Science in Public Administration, Professor, \\ Professor of the Department, e-mail: tsembalbogdan@ukr.net \\ c National University "Zaporizhzhya Polytechnic", Zaporozhye, Ukraine, \\ PhD, Associate Professor, Associate Professor of the Department, e-mail: kafedrales@ukr.net \\ ${ }^{D}$ National University of Civil Defence of Ukraine, Kharkov, Ukraine, \\ MSc, e-mail: tsembalbogdan@ukr.net \\ E National University of Civil Defence of Ukraine, Kharkov, Ukraine, applicant for higher education, \\ e-mail: tsembalbogdan@ukr.net
}

\begin{abstract}
This work presents an analysis of the existing methods for the occupational hazards assessing. A matrix for assessing the occupational hazard rate has been developed and the International Labour Organization methodology for the occupational hazard assessing has been improved. Five levels of the consequences severity, five levels of the probability of harm to the employee and the hazard rate from the minimum value of 1 (discarded hazard) to the maximum - of 10 (critical hazard) have been developed. In order to determine the hazard rate caused by any physical, chemical and biological danger factors, the frequency of accidents, the deficiencies in ergonomics and any psychological overloads, some criteria for the matrices were developed.
\end{abstract}


The consequences of the harm caused may be: minor, light, medium, severe and catastrophic. The improved methodology makes it possible to take into account the catastrophic consequences, that can occur during an emergency, such as fire, explosion, accident, disaster, etc. The probability of the occupational hazards may be: XS - from "eXtra Small" - very little, $S$ - from "Small" - little, M - from "Medium" - middle-sized, L - from "Large" - big, XL - from "eXtra Large" - very big and XXL - from "eXtra Large" - very-very big. The improved methodology defines the following: the discarded, insignificant, small, moderate, acceptable, admissible, significant, unacceptable, maximum and the critical hazard. The improved methodology for the occupational hazard assessing was tested at a dairy plant. The adequacy and the accuracy of the results of determining the occupational hazard rate of the improved methodology in comparison with the results of the existing one have been established. Some occupational hazard management measures were proposed and implemented for raising of the labor protection level.

Keywords: International Labour Organization, methodology for the occupational hazard assessing, advisory method, discarded hazard, acceptable hazard, catastrophic hazard, admissible hazard, dairy plant, labour protection measures, danger factors.

\section{References}

1. Ristić D., Stanković M., Savić S. (2008). Risk assessment matrices. Proceeding of 11th International Conference "Dependability and quality management». 580-587.

2. Stankovic M., Stanković V. (2013). Comparative analysis of methods for risk assessment "Kinney" and "Auva". Safety Engineering. 129-136.

3. Fedorets A. G. (2008). Metodicheskie osnovyi kolichestvennogo otsenivaniya proizvodstvennyih riskov. Energobezopasnost $i$ energosberezhenie. № 2 . URL: https://cyberleninka.ru/article/n/metodiche skie-osnovy-kolichestvennogo-otsenivaniyaproizvodstvennyh-riskov.

4. ELMERI. Posobie po nablyudeniyu za usloviyami truda na rabochem meste $v$ promyishlennosti. (2000). Institut professionalnogo zdravoohraneniya Finlyandii, Upravlenie po ohrane truda pri Ministerstve sotsialnogo obespecheniya $i$ zdravoohraneniya Finlyandii. 24 p. URL: http://base.safework.ru/safework?navigator \&spack $=110$ listid $=010000000100 \&$ listpos $=2$ $\& \mid s z=9 \& n d=444400008 \& n h=0 \&$.

5. Mervi Murtonen. (2007). Otsenka riskov na rabochem meste - prakticheskoe posobie: seriya Ohrana truda: Mezhdunarodnyiy opyit. Vyipusk 1. Subregionalnoe byuro MOT dlya stran Evropyi i Tsentralnoy Azii. 64 p. URL: http://www.studmed.ru/murtonen-m- ocenka-riskov-na-rabochem-mesteprakticheskoe-posobie-vypusk-1-opytfinlyandii_e79e78e5257.html\#.

6. Timofeeva S. S. (2016). Sovremennyie metodyi otsenki professionalnyih riskov $i$ ih znachenie v sisteme upravleniya ohranoy truda. Ohrana truda i promyishlennaya bezopasnost. № 1 (1). 14-24.

7. Rohach Yu. P. (2016). Praktychni pidkhody po otsintsi ryzyku neshchasnykh vypadkiv na pidpryiemstvakh APK. Naukove tovarystvo Smart and Young. №7. 76-81.

8. Bochkovskyi A. P. (2015) «Liudskyi faktor» ta ryzyk vynyknennia nebezpek: vypadkovist chy zakonomirnist. Yurydychna literatura. $137 \mathrm{p}$.

9. Bochkovskyi A. P. (2016). Teoretychni aspekty universalizatsii otsinky profesiinoho ryzyku $v$ systemakh upravlinnia okhoronoiu pratsi. Visnyk LDUBZhD. №14. 134-151.

10. Zaikina D. (2017). Development of the unified technique for the monitoring of occupational hazards at Kryvbas mining enterprises (Ukraine). Eastern-European Journal of Enterprise Technologies. V. 3. №10 (87). P. 1827.

11. Kolobylina O., Kravtsova S. (2013). Rozrobliannia kompleksnoi metodyky identyfikatsii nebezpek ta otsinky profesiinykh ryzykiv v umovakh vyrobnychoi diialnosti pidpryiemstv. Standartyzatsiia sertyfikatsiia yakist. №4. 32-37. 